\title{
Characteristics Of Present-Day Church Leaders
}

\author{
Mindo Judica Pangaribuan \\ \{mindojudica@gmail.com\} \\ STT Pelita Kebenaran
}

\begin{abstract}
The church is God's chosen people and is a manifestation and representation of the presence of Christ and His work in this world. A feature of a healthy church is characterized by a high quality leadership. This study aims to determine the characteristics of church leadership using a qualitative approach. The results of the study indicate that the characteristics of church leaders are: 1) ethical characteristics, namely the leader is a person who lives blamelessly, is faithful to his spouse and has children who have faith, and 2) have teaching that is in accordance with the truth of God's Word.
\end{abstract}

Keywords: Leadership, quality, church

\section{Introduction}

Leadership is important in an organization. The church, as a Christianinstitution, in its service to the congregation also requires healthy leadership. The Bible makes specific mention of acknkowledgementof the importance of leadership by asserting "For lack of guidance a nation falls, but victory is won through many advisers." Here the Bible puts into perspective the role of leaders in leadership as "crucial," because it determines the rise and fall of a group.

The health of the church cannot occur normally if the church does not yet have leadership. The first place that God begins to work at was to realize growth of churches in the hearts of leaders. Therefore there must be a growth of character or attitude, if this does not happen, the growth of the church will be inhibited. In terms of quantity the number of church leaders may increase, but in terms of quality it can be decreasing. This is because it is easy to become a leader in the church, as it is not a selective appointment. This is what is called the scarcity of qualified leaders in the post-modernization period.

Scarcity of leaders is also the result of the lack of adequate ministry preparation guidance before entering the christian ministry field. This mistake was brought to surface by Sue Mallory and Brad Smith in their book entitled 'The Equipping Church' in which they state as follows:

Many people mistakenly diffuse aquipping by the activities rather than by the results that accur. Equipping is more than apostling, prophesying, evangelizing, patoring, or teaching. A faulty understanding of equipping leads to overabundance of programs. We know that we've been equipping others when each individual does his part so that the whole body grows and loves. How much easier it would be if we were doing it. Scripture sets a much higher standard than just good sermons, plans, or programs. 


\section{Theoretical Review}

Leadership as a management function is very important to achieve an organizational goal. The process of implementing the duties and obligations of leaders is called leadership. Leadership is the nature of the leader in carrying out his moral and legal formal responsibilities for all the implementation of his authority which has been delegated to the people he leads.

Prajudi Atmosudirjo (in Hikmat, 2011: 251) explains leadership as "personality" of a person who brings a desire to a group of people to imitate or follow it, or that emits a certain influence, a strength or authority, so that a group of people is willing to do what he wants."

Leadership is an art, ability or technique to make a group of subordinates and formal organizations or followers or sympathizers in formal organizations follow or obey everything they want, making them enthusiastic or eager to follow it, maybe even willing to sacrifice for him (Hikmat, 2011: 252).

Based on various meanings above, it can be concluded that leadership is the ability of a leader to influence and mobilize other people to work together to achieve the goals of a group or organization.

According to R. Budiman, the characteristics needed for church leaders divided into 2 parts, namely the area of ethics and the area of teaching assignments. What is meant by characteristics in the ethical field is first, a leader who is blameless, Wesley Brill explains that what is meant by someone who is blameless means having a good name among church members and people outside the church. In addition, Mattew Henry gave his opinion about the reason leaders must live holy, not blemish so:

not absolutely without fault, so none are, for there is none that liveth and sinneth not; nor altogether unblamed, this is rare and difficult. Christ himself and his apostles were blamed, though not worthy of it. In Christ thee was certainly nothing blamable; and his apostles were not such as their enemies charged them to be. But the meaning is, He must be one who lies not under an ill character; but rather must have good report, even from those that are without; not grossly or scandalously guilty, so as would bring reproach upon the holy function; he must not be such a one.

This means that the leader must try to have healthy personal profile so that no one can accuse or harm him because of a mistake made.

Second, a husband who has only one wife. According to Wesley Brill, the husband of only one wife indicates that a church leader may only have one wife. If his wife dies or he divorces, he may not remarry. C.R Stam states that the husband of one wife implies the attitude of a believer.

Third, those whose children live in faith and cannot be accused of being indecent or disorderly. According to Warren W. Wiersbe, a child of a church leader must be a Christian and be saved. Wesley Brill explained that the children of church leaders must be educated in Christian beliefs and live according to their beliefs. The life of faith is a testimony for outsiders. If a church leader cannot manage his family then it is impossible to organize the church.

As for the characteristics in the area of teaching, is to hold on to the right words according to sound teachings. To hold fast to the truth means that you cannot deviate from the teachings of God found in the Bible that are never wrong. Paul M. Zehr explained that the task 
of church leaders is to teach and the call to teach includes not only teaching activities and skills but also the content of teaching that is appropriate to God's Word. Truth is not something that is found in human beings, but comes from God and God blesses those whose hearts and actions are right before Him.

In relation to church leadership, according to Stephen Tong, church leaders must be agents of God's truth who always bring, introduce and channel God's truth to the church. Stephen Tong further stated that good church leaders are those who always hold on to the truth of God and with all their hearts for life struggle with that truth by teaching about God's truth and having the right way of life to the church.

\section{Conclusion}

Leadership is an important element in the growth of the church. One characteristic of a healthy church is characterized by good leadership in the church. Leadership is the ability of a leader to influence and mobilize other people to work together to achieve the goals of a group or organization characterized by characteristics in the ethical field of leaders who are blameless, loyal to their partners and have children who have faith. Besides that, qualified leaders must also have the right teaching that is holding on to the right words in accordance with sound teachings that do not deviate from the teachings of God found in the Bible.

\section{References}

[1] Brill, Wesley.Tafsiran surat Timotius dan Titus. Bandung: Kalam Hidup. 1978.

[2] Matthew Henry's Commentary on the Whole Bible, Bahan Elektronik e-Sword.

[3] John, Scott.Isu-Isu Global Menantang Kepemimpinan Kristiani. Jakarta: Yayasan Komunikasi Kasih/OMF. 2000

[4] Lang, Stephen.Janji-Janji Alkitab. Bandung: Kalam Hidup. 2001

[5] Mallory, Sue dan Bard Smith, The Equipping Church. Michigan: Zondervan Grand Rapids. 2001

[6] Setiawani, Mary dan Stephen Tong. Seni Membentuk Persyaratan pribadi Kristen. Surabaya: Momentum. 2005.

[7] Wiersbe, Warren W.Setia di dalam Kristus Tafsiran I dan II Timotius dan Titus. Bandung: Kalam Hidup. 1996 